\title{
Effects of Land Use Change of Sloping Farmland on Characteristic of Soil Erosion Resistance in Typical Karst Mountainous Areas of Southwestern China
}

\author{
Rui Li*, Qinlin Wu, Jinjin Zhang, Yaqin Wen, Qinggui Li \\ ${ }^{1}$ School of Karst Science, Guizhou Normal University, Guiyang, Guizhou, P.R. China \\ ${ }^{2}$ State Engineering Technology Institute for Karst Desertification Control, Guiyang, Guizhou, P.R. China
}

Received: 12 June 2018

Accepted: 14 August 2018

\begin{abstract}
With the implementation of ecological projects such as the Grain-for-Green Project, rocky desertification control and comprehensive control of soil and water loss for sloping farmland, ecological environment of karst mountainous areas in southwest China has been improved significantly, but soil and water loss of sloping farmland is still an important ecological and environmental problem in this region. In this paper we took a typical karst rocky desertification mountainous area, Jinlan Demonstration Area, as the study area located in Qianxi County, Guizhou Province. On the basis of a previous experimental demonstration of grass planting and afforestation on sloping farmland (planted in 2014), the sample plot method was used to obtain soil samples and soil shearing test piece in 2017, and soil shear strength and soil erodibility factor $(K)$ were measured by direct shear method and hydrometer method in order to study the effect of sloping farmland converted to abandoned land, pastureland and agroforestry on soil erosion resistance. Results showed that the soil sheer strength was no obvious change and soil erodibility was no significant difference $(P>0.05)$ in sloping farmland with the level of rocky desertification becoming more serious; soil sheer strength greatly increased after sloping farmland was abandoned, ultimate shear strength $\tau_{300}$ was increased by $65.5 \%$, and $K$ was significantly different $(P<0.05)$ after 10 years; in the process of sloping farmland converted to pastureland, the soil ultimate shear strength $\tau_{300}$ was increased by $34.55 \%$ and $K$ decreased significantly $(P<0.05)$, which indicated that the effect of grass planting on improving soil erosion resistance of sloping farmland was obvious; in the process of sloping farmland converted to agroforestry, soil erosion resistance was also enhanced, soil shear strength was increased, and $K$ was decreased (it did not reach the significant level, $P>0.05$ ). Based on the preliminary results of this paper, we think both grass (tree) planting and land abandonment could improve soil erosion resistance and reduce soil erosion risk, which
\end{abstract}

*e-mail: rlfer@126.com 
are feasible non-engineering measures for soil and water conservation in the karst area of southwestern China.

Keywords: karst, rocky desertification, sloping farmland, land use, soil erodibility factor, soil erosion resistance

\section{Introduction}

Rocky desertification is a severe ecological problem in the subtropical karst area of southern China, which leads to rapid infertility of karst-weathered residual soil [1], like desertification in northwestern China, it is a fundamental and regional environmental problem of ecological construction in the development of western China, and it has become one of the main obstacles to regional sustainable development [2]. The overexploitation and unreasonable tillage practices caused by rapid population growth is the main human factor to accelerate and aggravate rocky desertification [3]. Barren soil, heavy and concentrated rainfall, and unreasonable tillage practices lead to soil loss and rock exposure, which lead to rocky desertification eventually. Therefore, soil and water loss is one of fundamental reasons for the occurrence and development of regional rocky desertification [4]. Sloping farmland is an important original place for soil and water loss [5], and soil erosion control in China is also dominated by soil erosion control of sloping farmland, thus it is of great practical significance to carry out basic research on soil erosion of sloping farmland.

Soil is one of the most important natural resources for sustaining biological life, and it plays an important role in agricultural production. Soil erosion causes negative impacts on land productivity and environmental quality, and degrades the socioeconomic status of farmers, so it poses a threat to livelihoods of landowners and overall ecosystem health [6]. There are many indexes to characterize soil erosion resistance, including Smith and Wischmeier suggesting the use of soil erodibility factor $K$ to characterize soil erosion resistance [7], and some scholars have suggested using soil aggression ratio, dispersion ratio and soil organic carbon to indicate soil erosion resistance [8-11], while Amezketa, Zhao Xiaoguang and others have used soil shear strength to characterize soil erosion resistance [12-13]. At present, soil erodibility factor is widely used, its connotation is the susceptibility of soil to erosion, and it is the key parameter for evaluating the sensitivity of soil erosion and an important basis for predicting soil erosion and evaluating its environmental effect [14]. When slope length and slope gradient (LS), coverage (C), rainfall characteristics (R) and management measures (M) are the same, soil erosion is only dependent on the inherent characteristics of soil [15]. Soil erosion is not only related to water, but also to land use/coverage change as they affect soil erodibility by changing the physical characteristics of soil [16].
Since the implementation of the Grain-for-Green Project in China in 1999, especially in the past 10 years, with the implementation of ecological control projects such as the special fund of rocky desertification control and comprehensive control of soil and water loss for sloping farmland, the rural land structure in the karst area has been continuously optimized and adjusted, and regional ecological environment and soil environments have been significantly improved [17-19]. In the process of ecological restoration, the land-use pattern changed, with farmland mainly converted to abandoned land, grassland and woodland. During the process of land use change in farmland, soil characteristics and soil erodibility both change to a different extent, and soil erosion resistance of surface soil is enhanced [20-22].

Compared with the Loess Plateau of northwestern China and the black soil region of northeastern China, there are few studies on soil erosion in the karst region of southwestern China, with the effects of the farmland converted to other land-use types on soil erosion resistance that is not reported. Taking the typical karst rocky desertification area in southwestern China as the study object, this paper discusses the effects of sloping farmland converted to other land-use patterns on soil shear strength and soil erodibility, which demonstrates the feasibility of non-engineering measures (planting trees and grass, abandoned land - natural restoration) for soil and water conservation, accumulate data for the subsequent basic research on soil erosion in the karst area and provide a theoretical reference for regional soil and water loss prevention, especially the comprehensive control of soil and water loss for sloping farmland.

\section{Materials and Methods}

\section{General Situation of the Study Area}

This study selected Jinlan Demonstration Area (located in Jinlan Town, Qianxi County, Guizhou Province of China) as the study area. The core demonstration area mainly consists of Houchang and Shuangqing administrative village in Jinlan Town, its longitude is $106^{\circ} 1^{\prime} 51.28^{\prime \prime} \mathrm{E} \sim 106^{\circ} 5^{\prime} 37.63^{\prime \prime} \mathrm{E}$ and its latitude is $26^{\circ} 51^{\prime} 71^{\prime \prime} \mathrm{N} \sim 26^{\circ} 52^{\prime} 58.98^{\prime \prime} \mathrm{N}$, the altitude is $1361-1563$ $\mathrm{m}$. Different rocky desertification degrees, potential, slight, moderate and severe rocky desertification land are widely distributed in this region, which is a typical karst rocky desertification area. The total land-use area of the core demonstration region is $560 \mathrm{hm}^{2}$, in which rocky desertification land accounts for $86 \%$. The annual 


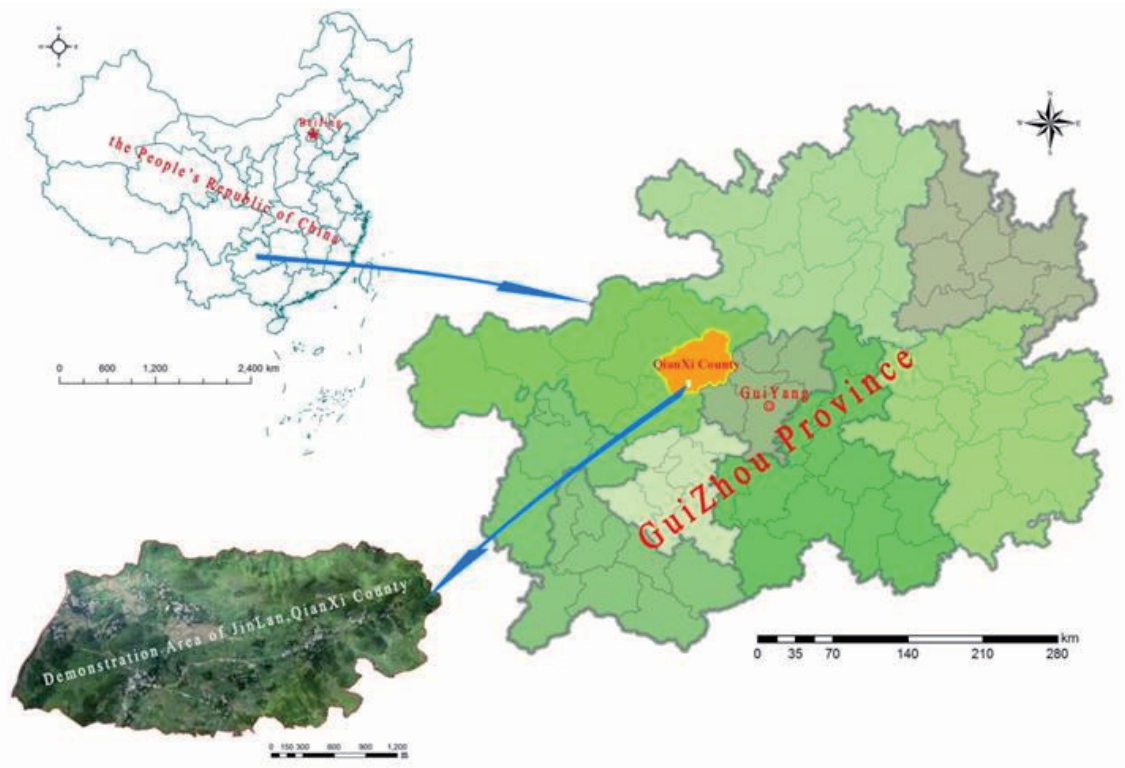

Fig. 1. Geographical location of the study area.

average temperature is $13.2^{\circ} \mathrm{C}$ and annual average rainfall is $980 \mathrm{~mm}$. The soil is dominated by yellow soil and yellow lime soil, yellow soil is zonal soil, and yellow lime soil is staggered. The geographical location of the study area is shown in Fig. 1.

\section{Layout of Sample Plots}

The types of field sample plot in this study area include the land use of sloping farmland, abandoned land, agroforestry and pastureland. Sloping farmland includes nil rocky desertification sloping farmland (NF), potential rocky desertification sloping farmland (PF) and slight-moderate rocky desertification sloping farmland (MF). Abandoned land includes 3-year abandoned land (A3) and more than 10-year abandoned land (A10), with A10 basically having been restored to natural shrubgrass land. Agroforestry just includes silvopasture (SP), in which the tree species includes Sichuan plum (Prunus salicina L.), Manaohong pomegranate (Punica granatum L.), etc., and the grass species mainly includes alfalfa (Medicago sativa L.) and Perennial Ryegrass

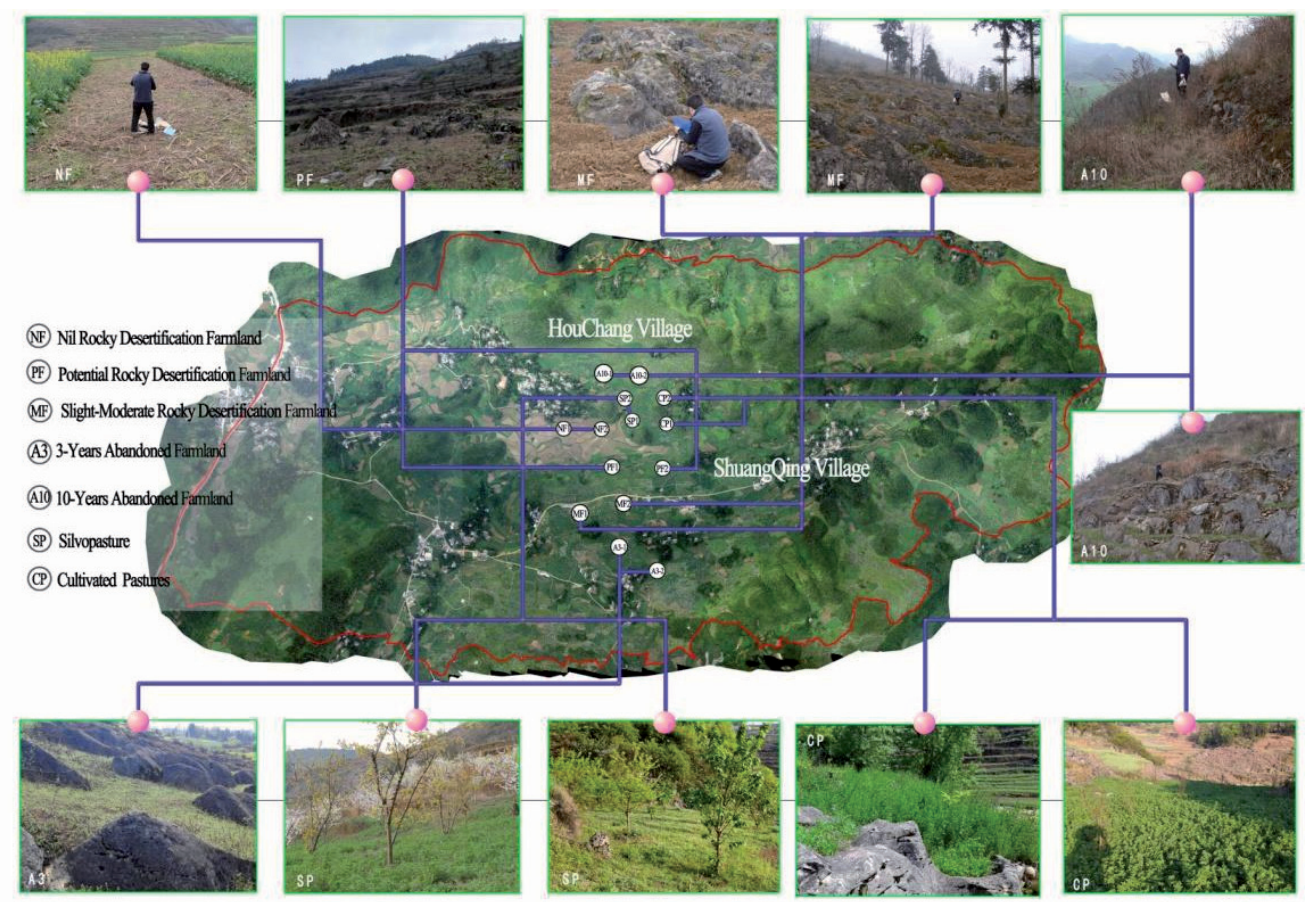

Fig. 2. Sketch map of sample plot layout. 
Table 1. Basic information of sample plots.

\begin{tabular}{|c|c|c|c|c|c|}
\hline $\begin{array}{l}\text { Type of } \\
\text { Land use }\end{array}$ & $\begin{array}{l}\text { Name of sample } \\
\text { plot }\end{array}$ & Identifier & Rocky desertification degree & $\begin{array}{l}\text { Center } \\
\text { point coor- } \\
\text { dinates }\end{array}$ & Planting status \\
\hline \multirow{6}{*}{ Farmland } & \multirow{2}{*}{$\begin{array}{l}\text { Nil rocky deserti- } \\
\text { fication farmland } \\
\qquad(\mathrm{NF})\end{array}$} & NF1 & Nil & $\begin{array}{l}\mathrm{E} 106^{\circ} 2.67^{\prime} \\
\mathrm{N} 26^{\circ} 52.04^{\prime}\end{array}$ & Zea mays, Brassica napus \\
\hline & & NF2 & Nil & $\begin{array}{l}\mathrm{E} 106^{\circ} 2.79^{\prime} \\
\mathrm{N} 26^{\circ} 52.06^{\prime}\end{array}$ & Zea mays, Brassica napus \\
\hline & \multirow{2}{*}{$\begin{array}{l}\text { Potential rocky } \\
\text { desertification } \\
\text { sloping farmland } \\
\text { (PF) }\end{array}$} & PF1 & Potential & $\begin{array}{l}\mathrm{E} 106^{\circ} 2.79^{\prime} \\
\mathrm{N} 26^{\circ} 51.97^{\prime}\end{array}$ & Zea mays, Brassica napus \\
\hline & & PF2 & Potential & $\begin{array}{l}\mathrm{E} 106^{\circ} 2.94^{\prime} \\
\mathrm{N} 26^{\circ} 51.98^{\prime} \\
\end{array}$ & Zea mays, Brassica napus \\
\hline & \multirow{2}{*}{$\begin{array}{c}\text { Slight-moderate } \\
\text { rocky desertification } \\
\text { sloping farmland } \\
\text { (MF) }\end{array}$} & MF1 & Light-moderate & $\begin{array}{l}\mathrm{E} 106^{\circ} 2.73^{\prime} \\
\mathrm{N} 26^{\circ} 51.87^{\prime}\end{array}$ & Zea mays \\
\hline & & MF2 & Light -moderate & $\begin{array}{l}\mathrm{E} 106^{\circ} 2.74^{\prime} \\
\mathrm{N} 26^{\circ} 51.88^{\prime}\end{array}$ & Zea mays \\
\hline \multirow{4}{*}{$\begin{array}{c}\text { Abandoned } \\
\text { land }\end{array}$} & \multirow{2}{*}{$\begin{array}{l}\text { 3-years abandoned } \\
\text { land (A3) }\end{array}$} & A3-1 & Light-moderate & $\begin{array}{l}\mathrm{E} 106^{\circ} 2.85^{\prime} \\
\mathrm{N} 26^{\circ} 51.79^{\prime}\end{array}$ & Abandoned \\
\hline & & A $3-2$ & Light-moderate & $\begin{array}{l}\mathrm{E} 106^{\circ} 2.93^{\prime} \\
\mathrm{N} 26^{\circ} 51.74^{\prime} \\
\end{array}$ & Abandoned \\
\hline & \multirow{2}{*}{$\begin{array}{l}\text { 10-years abandoned } \\
\text { land (A10) }\end{array}$} & A10-1 & Light-moderate & $\begin{array}{l}\mathrm{E} 106^{\circ} 2.78^{\prime} \\
\mathrm{N} 26^{\circ} 52.17^{\prime}\end{array}$ & Abandoned \\
\hline & & A10-2 & Light-moderate & $\begin{array}{l}\mathrm{E}^{106^{\circ}} 2.89^{\prime} \\
\mathrm{N} 26^{\circ} 52.16^{\prime}\end{array}$ & Abandoned \\
\hline \multirow{2}{*}{ Agroforestry } & \multirow{2}{*}{ Silvopasture (SP) } & SP1 & Potential & $\begin{array}{l}\mathrm{E} 106^{\circ} 2.86^{\prime} \\
\mathrm{N} 26^{\circ} 52.07^{\prime}\end{array}$ & Forest-grass compound planting \\
\hline & & SP2 & Potential & $\begin{array}{l}\mathrm{E} 106^{\circ} 2.84^{\prime} \\
\mathrm{N} 26^{\circ} 52.12^{\prime}\end{array}$ & Forest-grass compound planting \\
\hline \multirow{2}{*}{ Pastureland } & \multirow{2}{*}{$\begin{array}{l}\text { Cultivated pastures } \\
\text { (CP) }\end{array}$} & $\mathrm{CP} 1$ & Potential & $\begin{array}{l}\text { E106을 } 2.95^{\prime} \\
\text { N26 } 52.05^{\prime}\end{array}$ & $\begin{array}{l}\text { Medicago sativa, } \\
\text { Lolium perenne }\end{array}$ \\
\hline & & $\mathrm{CP} 2$ & Potential & $\begin{array}{l}\mathrm{E} 106^{\circ} 2.93^{\prime} \\
\mathrm{N} 26^{\circ} 52.13^{\prime}\end{array}$ & $\begin{array}{l}\text { Medicago sativa, } \\
\text { Lolium perenne }\end{array}$ \\
\hline
\end{tabular}

(Lolium perenne L.); the silvopasture had been planted for 4 years till field survey, and it was sloping farmland before planting. Planting varieties of cultivated pastures (CP, type of land-use was farmland before planted) mainly include perennial ryegrass, alfalfa and chicory (Cichorium intybus L.), and it also had been planted 4 years before the field survey. Each type of land-use set up 2 field sample plots, amounting to 14 sample plots. The location of sample plots is shown in Fig. 2, and basic information of the sample plots is shown in Table 1.

\section{Sampling and Analytical Test Method of Soil Samples}

Three soil sampling points were randomly assigned to each field sample plot, amounting to 42 sampling points. Test and analysis content of soil physical and chemical properties includes soil organic carbon, soil bulk density, soil particle size distribution and others. Because soil erosion often occurs in the topsoil layer, sampling depth of soil in this study was $0-20 \mathrm{~cm}$, and sampling time was February 2017.
Soil organic carbon was tested by potassium dichromate oxidation, soil particle size distribution was tested by hydrometer method, and soil bulk density was tested by metal cylinder method.

\section{Shear Samples Sampling Method and Soil Shear Strength Test Method}

The sampling point of soil shear samples was the same as the sampling point of soil samples as above, and four shear samples (shear tests were performed on 4 normal compressive stresses of $50 \mathrm{kPa}, 100 \mathrm{kPa}$, $200 \mathrm{kPa}$ and $300 \mathrm{kPa}$ respectively) taken around each sampling point accounted for $4 \times 42$ shear samples, sampling depth was also $0-20 \mathrm{~cm}$, and sampling time was May 2017. The basic method of sample preparation was found in the literature [23]. After samples were prepared completely in the field, the samples were packaged in sealed plastic bags and sent to the laboratory for natural air drying (reducing effect of water content on the shear results), then shear test was carried out. In this study, the rapid shear test was carried out with ZJ-2 strain-controlled direct shear apparatus. 


\section{Data Statistical Analysis Method}

\section{Index of Soil Shear Strength}

Indexes reflected soil shear strength include shear strain, shear stress and shear strength. The index of soil shear strength refers to the ultimate strength of soil against shear failure when it is subjected to external forces (rainfall scour, gravity and mechanical impact, etc.) [24]. According to Coulomb theory, the shear strength $\left(\tau_{f}\right)$ was composed of cohesive force (c) and frictional resistance $(\sigma \tan \varphi)$. The specific formula is as follows:

$$
\tau=\sigma \tan \varphi+\mathrm{c}
$$

In this formula, $\tau_{\mathrm{f}}$ is the soil shear strength $(\mathrm{kPa})$, $\sigma$ is the normal compressive stress on the shear plane $(\mathrm{kPa}), \varphi$ is soil internal friction angle $\left(^{\circ}\right)$ and $\mathrm{c}$ is soil cohesion.

\section{The Calculation Method of Soil Erodibility}

There are many calculation models of soil erodibility, such as the universal soil loss equation (USLE), the revised universal soil loss equation (RUSLE), erosion productivity impact calculator (EPIC) and Dg model. After comprehensive comparison, the EPIC was used to calculate soil erodibility factor $\mathrm{K}$ as following formula:

$$
\begin{gathered}
K=\{0.2+0.3 \exp [0.0256 \operatorname{SAN}(1-S I L / 100)]\}\left[\frac{S I L}{C L A+S I L}\right]^{0.3} \\
{\left[1.0-\frac{0.25 C}{C+\exp (3.72-2.95 C)}\right]\left[1.0-\frac{0.7 S N 1}{S N 1+\exp (-5.51+22.9 S N 1)}\right]}
\end{gathered}
$$

In this formula, SAN, SIL and CLA are sand, silt and clay content, respectively, $\mathrm{C}$ is the content of soil organic carbon, $S N 1=1-S A N / 100$. The result above uses the American soil particle size classification system, which is multiplied by 0.1317 and converted into the international soil particle classification system.

\section{Statistical Analysis and Mapping Tools}

Excel, SPSS 22.0 and Origin 8.5 were used for data collation, analysis, statistics and cartography.

\section{Results and Analysis}

\section{Effects of Land Use Change on Soil Shear Strength}

Table 2 was the experimental test value of soil internal friction angle and soil cohesion for different types of land use in the study area. According to the Coulomb theory, the ultimate shear strength of soil
Table 2. Soil internal friction angle and soil cohesion in the study area.

\begin{tabular}{|c|c|c|c|}
\hline Number & $\begin{array}{c}\text { Name of } \\
\text { sample plot }\end{array}$ & $\begin{array}{c}\text { Soil internal } \\
\text { friction angle } \\
\varphi\left({ }^{\circ}\right)\end{array}$ & $\begin{array}{c}\text { Soil cohesion } \\
\mathrm{c}(\mathrm{kPa})\end{array}$ \\
\hline 1 & NF & 22.40 & 42.7 \\
\hline 2 & PF & 24.76 & 31.2 \\
\hline 3 & MF & 25.55 & 38.9 \\
\hline 4 & A3 & 31.47 & 52.5 \\
\hline 5 & A10 & 38.50 & 46.0 \\
\hline 6 & SP & 31.93 & 44.0 \\
\hline 7 & CP & 32.54 & 39.2 \\
\hline
\end{tabular}

was determined by soil internal friction angle and soil cohesion.

Fig. 3 shows the ultimate shear strength of different land use patterns in the study area. The results showed that there was no obvious difference in the ultimate shear strength under four normal compressive stress



Fig. 3. Ultimate shear strength under different normal stresses $(\mathrm{kPa})$.

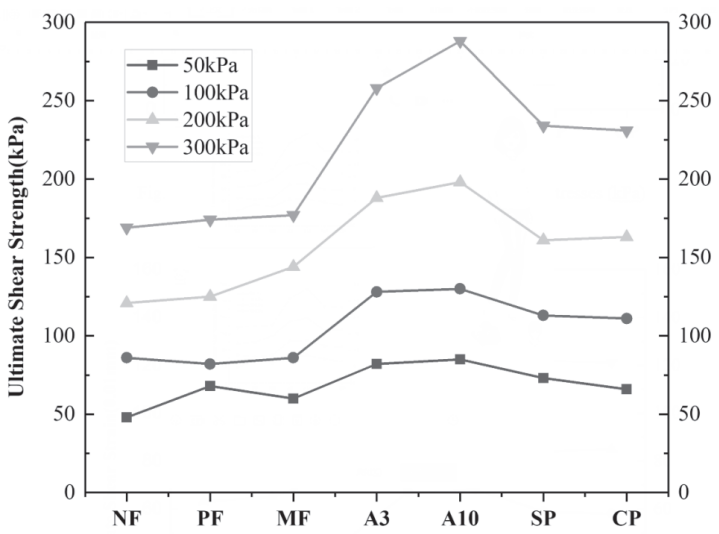

Fig. 4. Ultimate shear strain under different normal stresses $(0.01 \mathrm{~mm})$. 
Table 3. Soil erodibility factor $K$.

\begin{tabular}{|c|c|c|c|c|c|}
\hline \multirow{2}{*}{ Type of land use } & Name of sample plot & $\begin{array}{c}\text { Plot } \\
\text { number }\end{array}$ & $\begin{array}{c}\text { Sample } \\
\text { number }\end{array}$ & Range of variation & $\begin{array}{c}\text { Mean } \\
\text { value }\end{array}$ \\
\hline \multirow{3}{*}{ Sloping farmland } & Nil rocky desertification farmland (NF) & 2 & 6 & $0.0208-0.0237$ & $0.0221^{\mathrm{ab}}$ \\
\cline { 2 - 6 } & $\begin{array}{c}\text { Potential rocky desertification sloping farmland } \\
\text { (PF) }\end{array}$ & 2 & 6 & $0.0180-0.0239$ & $0.0227^{\mathrm{ab}}$ \\
\cline { 2 - 6 } & $\begin{array}{c}\text { Sight-moderate rocky desertification sloping } \\
\text { farmland (MF) }\end{array}$ & 2 & 6 & $0.0218-0.0335$ & $0.0260^{\mathrm{a}}$ \\
\hline \multirow{2}{*}{ Abandoned land } & 3-years abandoned land (A3) & 2 & 6 & $0.0220-0.0267$ & $0.0244^{\mathrm{ab}}$ \\
\cline { 2 - 6 } & 10-years abandoned land (A10) & 2 & 6 & $0.0133-0.0173$ & $0.0152^{\mathrm{c}}$ \\
\hline Agroforestry & Silvopasture (SP) & 2 & 6 & $0.0186-0.0237$ & $0.0217^{\mathrm{ab}}$ \\
\hline Pastureland & Cultivated pastures (CP) & 2 & 6 & $0.0168-0.0225$ & $0.0205^{\mathrm{b}}$ \\
\hline
\end{tabular}

Note: There was no significant difference in the same letter, there was significant difference in the different letter,

and the significance level was 0.05 .

in sloping farmland with different degrees of rocky desertification. Taking soil ultimate shear strength under normal compressive stress of $300 \mathrm{kPa}\left(\tau_{300}\right)$ as an example, NF was $169 \mathrm{kPa}$, PF was $174 \mathrm{kPa}$ and MF was $177 \mathrm{kPa}$, with the difference between them not being obvious. Results above showed that with the intensification of rocky desertification, the ultimate shear strength of sloping farmland has not changed much. The ultimate shear strength of soil changed greatly after the sloping farmland was converted to abandoned land, during the change process of $\mathrm{PF} \rightarrow \mathrm{A} 3 \rightarrow \mathrm{A} 10, \tau_{300}$ increased from $174 \mathrm{kPa}$ to $258 \mathrm{kPa}$ and $288 \mathrm{kPa}$ respectively, the rates of increase were $48.3 \%$ and $65.5 \%$ respectively, indicating that the soil shear strength increased continuously with the prolongation of abandoned time of sloping farmland, which was closely related to vegetation restoration and soil root increasing. From the change process of $\mathrm{PF} \rightarrow \mathrm{SP}$, the soil shear strength was also increased, $\tau_{300}$ was increased from $174 \mathrm{kPa}$ to $234 \mathrm{kPa}$ with an increase rate of $34.5 \%$. The soil shear strength also increased obviously during the change process of $\mathrm{PF} \rightarrow \mathrm{CP}, \tau_{300}$ increased from $174 \mathrm{kPa}$ to $231 \mathrm{kPa}$ with an increase rate of $32.8 \%$.

The results of ultimate shear strain under different types of land use are shown in Fig. 4, where the effect of land use change on soil shear strain was the same as soil shear strength.

\section{Effects of Land Use Change on Soil Erodibility}

The effect of land use change in sloping farmland on soil erodibility in the study area was shown in Table 3. The K-values of 3 different degrees of rocky desertification sloping farmland were NF 0.0221, PF 0.0227 and MF 0.0260 , respectively. It can be seen that with the intensification of rocky desertification, the soil erodibility change of sloping farmland was not obvious, that is, soil erosion resistance did not change significantly with the increase of rocky desertification degree and there was no significant difference in soil erosion resistance among them $(P>0.05)$, which was basically consistent with the results of soil sheer strength mentioned above.

The K-value of 3-year abandoned land was 0.0244 , which decreased by $6 \%$ compared with MF, which indicated that the soil erodibility did not change obviously after having been abandoned for 3 years, and comparing with NF, PF and MF, soil erodibility was no significant difference $(P>0.05)$; the K-value of A10 was 0.0152 , and it had an obvious change compared with NF, PF and MF. A significant test showed that it was significantly lower than NF, PF and MF $(P<0.05)$, but there was no significant difference between A3 and A10. The results above showed that the soil erosion resistance of slopping farmland did not change much after 3 years of abandonment; however, after more than 10 years of abandonment it increased significantly.

The K-values of SP and CP were 0.0217 and 0.0205 , respectively (Table 3). Soil erodibility of SP and CP decreased to a certain extent, that is, soil erosion resistance for SP and CP was improved. Further significant tests indicated that it had no significant difference between SP and the three degrees of rocky desertification sloping farmland mentioned above $(P>0.05)$. However, there was a significant difference between $\mathrm{CP}$ and MF $(P<0.05)$, that is, soil erosion resistance had been improved significantly after planting grass for 3 years in sloping farmland (the grass was planted in 2014). Although sloping farmland to silvopasture for 3 years, soil erosion resistance improved to some extent, but it had not reached a significant level $(P>0.05)$; it was not known whether soil erosion resistance of silvopasture would be significantly improved with the extension of planting time, but we will continue to study it in the future. 
Table 4. Pearson correlation between soil erodibility and related soil indicators.

\begin{tabular}{|c|c|c|c|c|c|}
\hline Statistical quantity & Organic carbon & Soil bulk density & Clay content & Silt content & Sand content \\
\hline Pearson correlation & $-0.644^{* *}$ & $0.510^{* *}$ & $0.425^{* *}$ & $0.902^{* *}$ & $-0.712^{* *}$ \\
\hline Significant (bilateral) & 0.000 & 0.001 & 0.005 & 0.000 & 0.000 \\
\hline Covariance & -0.002 & 0.000 & 0.010 & 0.021 & -0.026 \\
\hline N & 42 & 42 & 42 & 42 & 42 \\
\hline
\end{tabular}

**. Indicates significant correlation at level 0.01 (bilateral)

\section{Conclusion and Discussion}

\section{Conclusion}

1) During the transition process of $\mathrm{NF} \rightarrow \mathrm{PF} \rightarrow \mathrm{MF}$, soil ultimate shear strength (strain) and soil erodibility did not change significantly, which showed that soil erosion resistance of sloping farmland did not change significantly with increased rocky desertification grade.

2) In the process of sloping farmland converted to abandoned land, soil erosion resistance was improved and soil erodibility of 10-year abandoned land was significantly decreased; at the same time, soil ultimate shear strength and ultimate shear strain increased greatly in the process of sloping farmland abandonment. This showed that soil erosion resistance was greatly improved with the prolonged abandonment time.

3) In the process of sloping farmland converted to cultivated pastures and silvopasture, ultimate shear strength (strain) was increased and soil erodibility factor was decreased, which showed that soil erosion resistance was enhanced when sloping farmland converted to cultivated pastures and silvopasture.

\section{Discussion}

\section{The Main Influencing Factors of Soil Erodibility}

The Pearson correlation relationships between soil erodibility and soil properties (soil organic carbon, soil bulk density and clay content) are shown in Table 4. It can be seen from the table that there was a significant negative correlation between soil erodibility and soil organic carbon in the study area $(P<0.01)$, indicating that soil erodibility decreased with an increase in soil organic carbon, which was consistent with research conclusions of other scholars in the Loess Plateau region of China [25], the purple soil region of Southern China [26] and red soil region of Southern China [27], but the similar reports have not yet been seen in the karst region of southwestern China. Therefore, increasing soil organic carbon content will not only increase soil fertility, but also increase soil erosion resistance. Sand content and soil erodibility have a significant negative correlation, meaning that soil erosion resistance improved with the increase of sand content [28]. As we know, under the raindrop splash (splash erosion) and sheet flow scouring (sheet erosion), soil with smaller particle size is the first to be stripped and transported, while the sand is larger in size and it is often difficult to be stripped and transported, therefore, the increase of sand content can strengthen soil erosion resistance. However, some studies have shown that erodibility is positively correlated with soil sand content [27], soil erosion resistance decreased with the increase of sand content, which may be related to different methods used and soil conditions in the study area. Soil erodibility showed significant positive correlation with soil bulk density, clay content and silt content $(P<0.01)$, which indicated that with the increase of soil bulk density, clay content and silt content, soil erodibility in the study area showed an increasing trend, that is, soil erosion resistance decreased.

Limited by the purposes of this study, this paper has not studied other indexes of soil properties that may affect soil erodibility, such as soil aggregates, so we will carry out research in the future and continue to observe the above-mentioned factors.

\section{Study of Soil Mechanics Mechanism}

Soil mechanics mechanism is an important research content of soil erosion and soil and water conservation, and researchers mainly elucidate the vegetation regulating role through shear strength of the soil-root composite system [29-31]. Compared with the regulation mechanism of ground vegetation on soil and water loss, the study of underground root systems on soil and water conservation is much less, which is mainly caused by the study of an underground root system being relatively difficult [32]. However, studies in the past two decades have shown that plant roots play a leading role in reducing soil erosion rate on slope, so they can effectively regulate soil erosion [33]. Because of the existence of a root system, soil shear strength is greatly enhanced [34], which is often used to protect surface soil from human disturbance [35-36]. Related studies show that enhancement of soil shear resistance by plant roots depends on root characteristics and it is endemic to plants, such as root structure and root tensile strength [37]. The shear strength of the root-soil composite system 
is negatively related to the diameter of root, that is, the finer the root system, the greater shear strength of rootsoil composite system [38]. When we predicate slope erosion rate, soil shear strength is an important factor to be considered, because soil shear strength is positively correlated with critical runoff shear stress $\left(\tau_{\mathrm{cr}}\right)$, and it is negatively correlated with soil erodibility factor $(K)$ [39-40]. It can be seen that sheer strength of the root-soil composite system plays an important role in resisting runoff erosion on the slope, so shear characteristics of the root-soil composite system should be considered in the study of the soil erosion mechanism.

The purpose of this paper is to study soil ultimate shear strength in different land use, so the effect of soil root characteristics and distribution on soil shear strength was not carried out. However, from the preliminary conclusions of this paper, it can be seen that soil shear strength increased to a different extent, whether slope farmland was converted into abandoned land, pastureland or agroforestry land. In fact, farmland converted into abandoned land, pastureland and agroforestry land reduces human activity and increases soil root number, thus affecting ultimate shear strength of soil. However, we know that there are great differences in characteristics of different plant root systems in soil, such as distribution and interweaving, so the shear strength of soil-root composite system composed of root system and soil is also different. At present, just a few studies on the mechanics mechanism of soil erosion in the karst area of southwestern China [41-42] and the related mechanical experiments of rootsoil composite system have not been reported. In our next research stage we will carry out a soil mechanics test of soil-root composite system on different planting measurements of soil and water conservation to provide reference for plant selection on soil and water loss prevention in the karst area.

\section{Soil and Water Loss Control of Sloping Farmland in the Karst Rocky Desertification Area of Southwestern China}

Sloping farmland is the main original place for soil and water loss [5], which is a reason for the Chinese government to set up a special fund for comprehensive control of soil and water loss of sloping farmland. At present, the main measurements for the project are engineering measures, such as transforming sloping farmland to terraces, intercepting drain, reservoir, and drain ditch and so on; however, because of the investment limit of the special fund, fragile terrain and difficulty for transforming sloping farmland to terraces by machine, the scope of harness is still relatively limited. Compared with engineering measures, planting measures have characteristics of investment saving, good benefit (ecological benefit and economic benefit), and it is suitable for karst area with characteristics of topography in pieces. However, for poor karst mountainous areas, people are more concerned about economic benefits than ecological benefits. The practice of soil and water loss control of sloping farmland in the karst area has shown that most planting measures with poor economic benefits ended in failure, for example Lonicera hypoglauca planting was organized by the government of Southwestern Guizhou Autonomous Prefecture many years ago, and the effect of soil and water conservation on sloping farmland was not bad; however, because of poor economic benefit, farmers cut Lonicera hypoglauca down and replanted Zea mays, and soil erosion was further aggravated. Therefore, planting measures on soil and water loss control should be adapted to local conditions, meet regional natural and socio-economic characteristics and market demand, and the selected plant species should have good ecological and economic benefits. In short, soil and water loss control of sloping farmland in the karst area should be carried out closely around the aim of povertyalleviation in order to realize coordinated and sustained development of ecological and economic benefits.

\section{Acknowledgements}

The authors are grateful for support by the National Natural Science Foundation of China (31760243); the Basic Research Foundation of Guizhou Province (Qiankehe Jichu [2018]1112); the Technology Research and Development Program of Guizhou Province(Qiankehe Zhicheng [2019]2847); the Foundation of Guizhou Forestry Department (QianLinKeHe [2017]13); the Foundation of Guizhou Water Resources Department (KT201806) and the Ph.D. Early Development Program of Guizhou Normal University (2017).

\section{Conflict of Interest}

The authors declare no conflict of interest.

\section{References}

1. YUAN J., XU F., DENG G., TANG Y. Using stable isotopes and major ions to identify hydrogeochemical characteristics of karst groundwater in Xide country, Sichuan Province. Carbonates and Evaporites, 33 (2), 1, 2017.

2. ZHANG M.Y., WANG K.L., LIU H.Y. Effect of ecological engineering projects on ecosystem services in a karst region: A case study of northwest Guangxi, China. Journal of Cleaner Production, 183, 831, 2018.

3. JIANG Z.C., LIAN Y.Q., QIN X.Q. Rocky desertification in Southwest China: Impacts, causes, and restoration. Earth-Science Reviews, 132 (3), 1, 2014.

4. LI R., LI Y., XIONG K.N. Regulating effects on soil and water loss of typical slope land use patterns and tillage methods in karst area of central Guizhou province. Bulletin of Soil and Water Conservation, 37 (6), 136, 2017 
5. LI R., ZHANG C., GU Z.K. Response of soil erosion to main influencing factors on hillslope of typical watersheds in Guizhou karst area. Research of Soil and Water Conservation, 25 (3), 1, 2018.

6. AJIBOLA Y.H., GBENRO O.P., KHADIJAH L.A. Land use effects on soil erodibility and hydraulic conductivity in Akure, Nigeria. African Journal of Agricultural Research, 13 (7), 329, 2018.

7. WISCHMEIER, W.H., SMITH D.D. Predicting rainfall erosion losses - a guide to conservation planning. Agric Handbook, 537, 1978.

8. BRYAN R.B. The development, use and efficiency of indices of soil erodibility. Geoderma, 2 (1), 5, 1968.

9. WISCHMEIER, W.H., MANNERING J.V. Relation of soil properties to its erodibility. Soil Science Society of America Proceedings, 33 (1), 131, 1969.

10. ÖZDEMIR N. Effects of admixturing organic residues on structure stability and erodibility of soils. Ataturk University, Journal of the Faculty of Agriculture, 24 (1), 75,1993

11. LAL R. Soil erosion research methods. CRC Press, 1994.

12. LI D.J, WEN L., JIANG S., SONG T.Q., WANG K.L. Responses of soil nutrients and microbial communities to three restoration strategies in a karst area, southwest china. Journal of Environmental Management, 207, 456, 2017.

13. ZHANG M.Y., WANG K.L., LIU H.Y., ZHANG C.H., YUE Y.M., QI X.K. Effect of ecological engineering projects on ecosystem services in a karst region: A case study of northwest Guangxi, China. Journal of Cleaner Production, 183, 831, 2018.

14. WANG B., ZHENG F., RÖMKENS M.J.M. Comparison of soil erodibility factors in USLE, RUSLE2, EPIC and Dg models based on a Chinese soil erodibility database. Acta Agriculturae Scandinavica, Section B-Soil and Plant Science, 63 (1), 69, 2013.

15. XIONG K.N., CHI Y.K., SHEN X.Y. Research on photosynthetic leguminous forage in the karst rocky desertification regions of southwestern China. Polish Journal of Environmental Studies, 26 (5), 2319, 2017.

16. VIJI R., PRASANNA P.R. Assessment of soil erodibility by using geographic information system. Asian Journal of Research in Social Sciences and Humanities, 7 (1), 483, 2017.

17. JIANG Z., LIAN Y., QIN X. Rocky desertification in southwest China: impacts, causes, and restoration. Earth Science Reviews, 132 (3), 1, 2014.

18. HUANG X.F., ZHOU Y.C., ZHANG Z.M. Distribution characteristics of soil organic carbon under different land uses in a karst rocky desertification area. Journal of Soil and Water Conservation, 31 (5), 215, 2017.

19. WU Q.L., LIANG H., XIONG K.N. Frontier theories and countermeasures for integrated regulation of soil and water loss and mountainous agroforestry in rocky desertification environment. Journal of Soil and Water Conservation, 32 (2), 11, 2018.

20. YANG F., ZHANG H.J., CHEN J.H. Soil erodiblity of different land use types in Yanqing County of Beijing City. Bulletin of Soil and Water Conservation, 33 (6), 19, 2013.

21. ZHAI Z.M., WANG K.Q., SU B., ZHANG X.Q., HUA J.X., ZHU X.T. Study on soil erodibility of different land utilization styles in the songhuaba eater source rea. Journal of Southwest Forestry University, 36 (5), 118, 2016.

22. WANG H., ZHANG G.H., LI N.N. Soil erodibility influenced by natural restoration time of abandoned farmland on the Loess Plateau of China. Geoderma, 325, 18, 2018.
23. LI H.T., LI G.R., ZHAO Y.J. Characteristics of slope soil shear strength reinforced by vegetation roots under artificially simulated rainfall condition. Transactions of the Chinese Society of Agricultural Engineering, 32 (4), 142, 2016.

24. LI Y.P., WANG Y.Q., WANG Y.J., ZHANG H.L., ZHU J.Q. Characteristics of soil shear failure of different forests and its affecting factors in Jinyun mountain, Chongqing City .Chinese Journal of Soil Science, 44 (5), 1074, 2013.

25. WU L.H., WANG S.J., BAI X.Y., LUO W.J., TIAN Y.C., ZENG C., LUO G.J., HE S.Y. Quantitative assessment of the impacts of climate change and human activities on runoff change in a typical karst watershed, SW China. Science of the Total Environment, 601, 1449, 2017.

26. MA Y., HE B.H., HE J.L., CHEN Y., GUO T., HUANG W., LI J.X. Effects of herba andrographitis hedgerow on soil fractal characteristics and erodibility on sloping cropland in three gorges reservoir region. Journal of Soil and Water Conservation, 25 (4), 79, 2011.

27. DENG Y., DING S., XIA D. Soil erodibility and physicochemical properties of alluvial fan of collapsing gullies in South China. Pedosphere, 2017. Doi: 10.1016/ S1002-0160(15)60105-9.

28. ZHANG Z.M., ZHOU Y.C., WANG S.J., HUANG X.F. Soil organic carbon density spatial distribution and influencing factors in a karst mountainous basin. Polish Journal of Environmental Studies, 26 (5), 2363, 2017.

29. ZHANG Z.M., ZHOU Y.C., WANG S.J., HUANG X.F. Comparing Estimation Methods for Soil Organic Carbon Storage in Small Karst Watersheds. Polish Journal of Environmental Studies, 27 (4), 1879, 2018.

30. CAO Y.S., CHEN L.H., GAI X.G. Soil reinforcement by pinus tabuliformis roots. Bulletin of Soil and Water Conservation, 34 (5), 6, 2014.

31. LU C.J., CHEN L.H., CHEN W.G. Study on shear performance of soil-root composite. Journal of Irrigation and Drainage, 35 (3), 13, 2016.

32. VANNOPPEN W., VANMAERCKE M., DE B.S. A review of the mechanical effects of plant roots on concentrated flow erosion rates. Earth Science Reviews, 150, 666, 2015.

33. WU F., LIU C.W, Chen H.K., DIAO Z.F., ZHAO S., XIE H. Use of nutrient medium technique for vegetation restoration in Karst region of Southwest China. Journal of Integrative Environmental Sciences, 15 (1), 139, 2018.

34. HE Z.H., LIANG H., YANG Z.H., HUANG F., ZENG $X$. Water system characteristics of karst river basins in south China and their driving mechanisms of hydrological drought. Natural Hazards, 99 (2), 1, 2018.

35. MAO Z., SAINT L., GENET M. Engineering ecological protection against landslides in diverse mountain forests: choosing cohesion models. Ecological Engineering, 45 (10), 55, 2012.

36. STOKES A., DOUGLAS G.B., FOURCAUD T. Ecological mitigation of hillslope instability: ten key issues facing researchers and practitioners. Plant and Soil, 377 (1), 1, 2014.

37. SU C., ZOU S., TANG J., LIANG B. Influence of different ecosystems on the soil moisture and karst effect in Luota, west Hunan province of China. Chinese Journal of Ecology, 31 (8), 1, 2012.

38. LIU C., LIU Y., GUO K. Effects of nitrogen, phosphorus and potassium addition on the productivity of a karst grassland: Plant functional group and community perspectives. Ecological Engineering, 117, 84, 2018. 
39. HU Y., XIA Y., SUN Q., LIU K., CHEN X., GE T. Effects of long-term fertilization on phoD -harboring bacterial community in Karst soils. Science of the Total Environment, 628, 53, 2018.

40. WANG J., LI Z., CAI C. Predicting physical equations of soil detachment by simulated concentrated flow in Ultisols (subtropical China). Earth Surface Processes and Landforms, 37 (6), 633, 2012.
41. GAO H.D., SUN Q.Z., YUAN Y. Characteristics of soil erosion for different land types in karst areas. Bulletin of Soil and Water Conservation, 30 (2), 92, 2010.

42. SUN Q.Z., GAO H.D., LIU R.L., YANG S.Q., NING M.Q., NIU M. Effects of soil mechanical properties on soil erosion in karst area of Guizhou center. Journal of Soil and Water Conservation, 24 (6), 38, 2010. 